\title{
Clinical, biochemical, and immunoelectrophoretic study of subretinal fluid
}

\author{
A. H. GHignelL, M. GARRUThers, AND A. H. S. RAHI \\ From the Retinal Unit, Moorfields Eye Hospital, City Road, and the Department of Pathology, \\ Institute of Ophthalmology, University of London
}

Subretinal fluid found in retinal detachments associated with retinal tears is derived from the vitreous, or from the choroidal vessels, or both. The relatively high concentration of protein found in subretinal fluid argues mainly in favour of the protein being derived from the choroidal vessels. Examinations of total protein concentration in subretinal fluid have been made by several workers. Smith and Douty (ig6o) and Heath, Beck, and Foulds ( 1962 ) found that the total protein concentration of the subretinal fluid tended to rise with an increase in the duration of the detachment. Heath \& others (1962) felt that the rise in total protein concentration indicated an increasing permeability of the choroidal capillaries; they also found a marked increase in total protein in eyes which had undergone more than one operation. Weber and Wilson (1963) confirmed the protein findings and later stated (Weber and Wilson, 1966) that they thought the formation of subretinal fluid was a dynamic process. Cooper, Halbert, and Manski (1963), using immunoelectrophoresis, showed large numbers of serum proteins in the fifteen cases of subretinal fluid examined. Manuel, Royer, Richard, and Creyssel (1960), examining subretinal fluid by immunoelectrophoresis, found a " $\gamma$ " precipitin band. Speiser (I964) used a similar technique in examining eleven cases and found serum-like proteins when the total protein concentration was high, but with lower protein concentrations the globulins were relatively reduced, and with very low total protein concentrations only albumin could be detected.

The purpose of this communication is to report the total protein concentrations and immunoelectrophoretic examinations of 28 specimens of subretinal fluid obtained from 26 patients suffering from retinal detachment. The technique of immunoelectrophoresis used in this study has enabled a more detailed examination of the subretinal fluid to be made than has hitherto been reported. It has allowed in particular a detailed examination of the $\gamma$-globulin fraction of the subretinal fluid. The presence or absence of IgG, IgA, and IgM may be detected, and thus it is possible to assess the degree of permeability of the choroidal capillaries and Bruch's membrane in retinal detachments.

\section{Method}

COLLECTION AT OPERATION

The area around the proposed site of scleral puncture was carefully dried. Scleral puncture was 
made immediately after the application of cryotherapy. Subretinal fluid was collected by placing dried, sterilized, 20- $\mu$ l. glass capillary tubing in the stream of subretinal fluid emerging from the puncture site. These tubes were then sealed and stored at $4^{\circ} \mathrm{C}$. and analysed as soon as possible.

\section{ANALYSIS}

\section{Total protein}

This was measured by micro-Kjeldahl digestion followed by nitrogen estimation with Nessler's reagent. To enable the protein electrophoretic pattern of the subretinal fluid to be compared with that of plasma from the same patient, a drop of fluid was concentrated by rapid evaporation in a stream of warm air. The concentrated fluid was then placed in one "foot" of the multiapplicator, the patient's plasma was placed in an adjacent foot, and cellulose acetate electrophoresis was performed with Ponceau S staining (Carruthers, 1970). The identical conditions for migration and staining enabled the subretinal fluid and plasma patterns to be correlated, both by inspection and by scanning on a Wooster Mark III Microdensitometer. The results obtained were expressed in g./ $100 \mathrm{ml}$.

\section{IMMUNOELECTROPHORESIS}

This was performed on agar plates based on the microtechnique proposed by Scheidegger (1955) as an improvement on the original technique of Grabar and Williams (1953). $8 \mathrm{ml}$. of $\mathrm{I} \cdot 5$ per cent. I.D. agar (oxoid) in veronal buffer ( $\mathrm{pH} \mathrm{8.2;} \mathrm{I}=0.05)$ to which sodium azide was added to give a concentration of $\mathrm{I}$ : 1000 was poured over a previously coated $8 \times 8 \mathrm{cu} . \mathrm{cm}$. glass slide (Kodak) and allowed to set in a moist chamber overnight. Circular wells $\mathrm{I} \mathrm{mm}$. in diameter were cut along the middle of the plate $10 \mathrm{~mm}$. apart and filled with subretinal fluid using a micropipette. Normal human serum was put into one of the wells for comparison. The plate was then put upside down on the shoulder piece of the electrophoresis tank (Shandon $\mathrm{U}_{77}$ after Kohn) and connected to electrode compartments containing barbitone buffer $(\mathrm{pH} 8.6 ; \mathrm{I}=0.075)$ by thick filter paper strips. The current was adjusted to Io $\mathrm{mA} /$ per plate and allowed to run for $2 \mathrm{hrs}$. After electrophoresis the plate was removed and troughs $(60 \times 1 \mathrm{~mm}$.) were cut equidistant between the wells, along the direction of electrophoretic migration. Strips of agar were removed by applying suction. The troughs were then filled with antihuman multivalent and monospecific sera and the plate was then left in a moist chamber for 2 days. The plate was then washed with 3 per cent. saline for 2 days to remove unprecipitated proteins. After further washing in distilled water for $4 \mathrm{hrs}$ the plate was covered by lint-free filter paper and completely dried in an incubator at $37^{\circ} \mathrm{C}$. After removal of the filter paper the plate was stained in 0.2 per cent. Ponceau $S$ or 0.1 per cent. nigrosine to pick up fine precipitin lines, otherwise barely visible. According to the nature and number of precipitin lines, as compared with normal human serum the subretinal fluids were divided into three main groups:

Group $A$ Possessed almost all the constituents of normal serum and showed prominent precipitin bands for albumin, $\alpha_{1}$ antitrypsin, group-specific component (Gc)-globulin, haptoglobin, transferrin, haemopexin, IgG and IgA.

Group B Possessed all the constituents shown in Group A, with the exception of IgA which was absent.

Group $C$ Possessed few of the constituents of normal human serum. Only albumin, traces of IgG, and transferrin were found.

Three cases showed the characteristics of Group B, but minute traces of IgA were found and they were indicated as belonging to Group A-B. Examples of the results obtained from immunoelectrophoresis are shown in Figs I-4 (opposite and overleaf). 


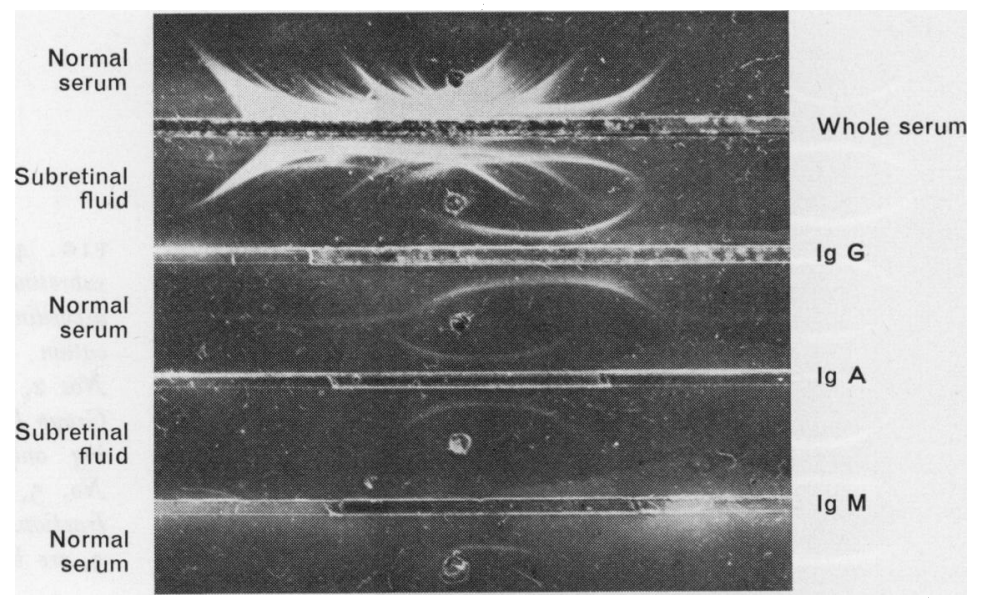

FIG. I Sample of subretinal fluid tested against antihuman "whole" or multivalent serum (WS) and mono-specific sera against immunoglobulins $G, A$, and $M$. This sample would be classified under Group $A$ as only IgM is absent

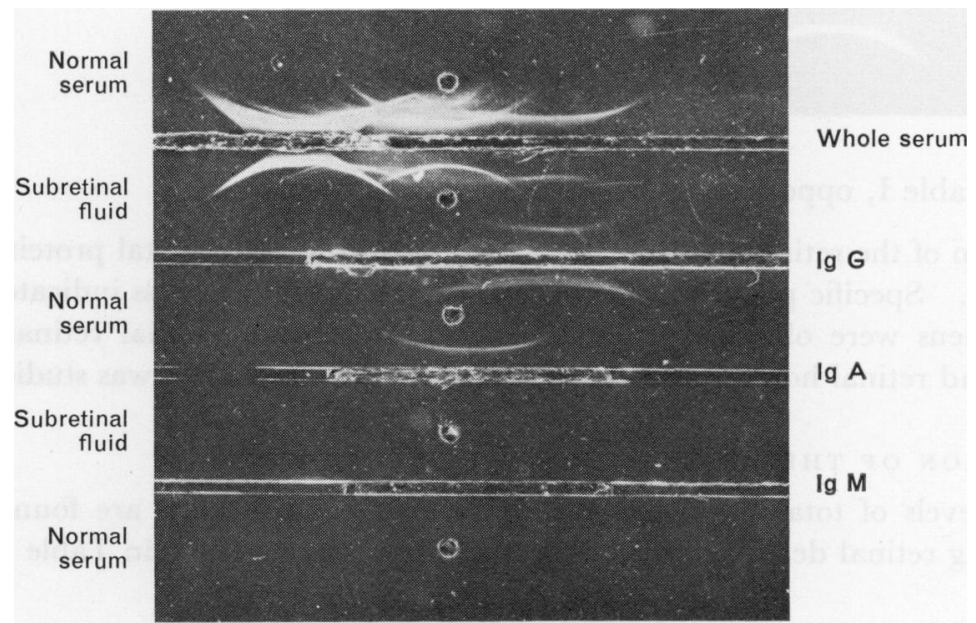

FIG. 2 Subretinal fuid of Group B pattern, where IgA as well as IgM is absent

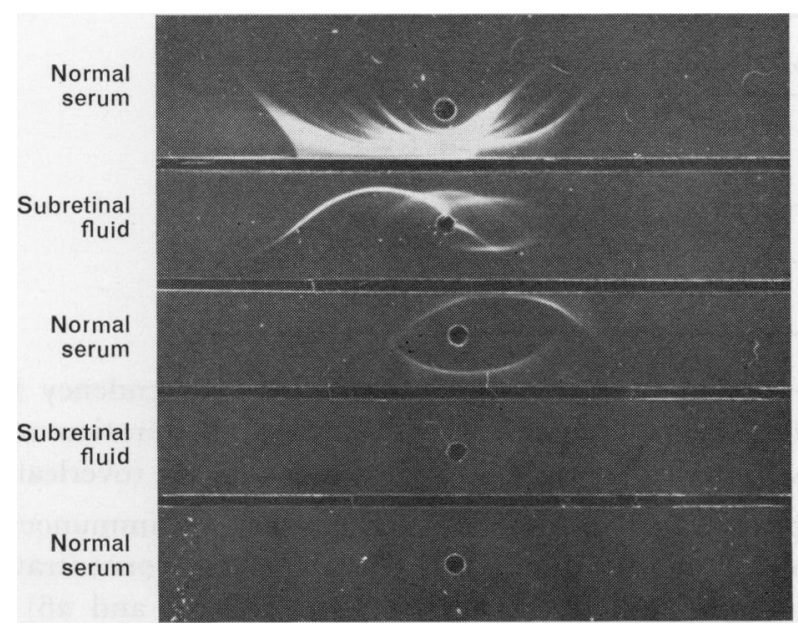

Whole serum

FIG. 3 Subretinal fluid of Group C pattern, where albumin and only traces of IgG and transferrin are present

$\lg \mathrm{A}$

$\lg M$ 


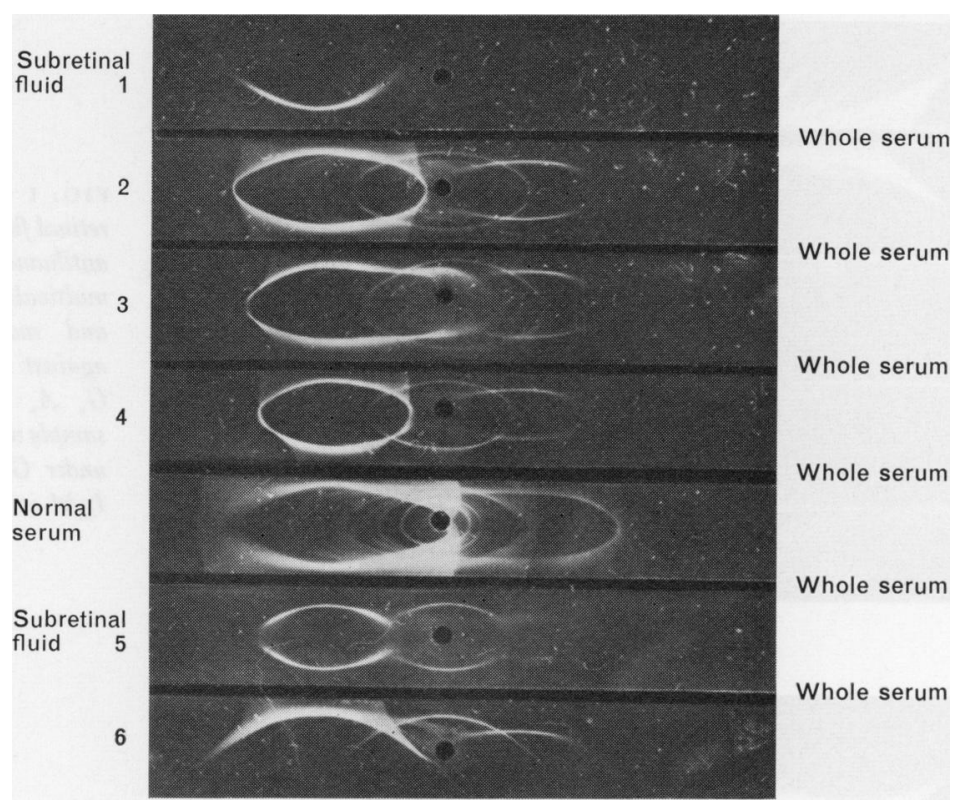

FIG. 4 Group of six subretinal fluids, of which according to the classification described above, के Nos 2, 3, 4, and 6 are $\vec{\circ}$ Group B. No I, showing only albumin and $\vec{\omega}$ No. 5, showing all the fractions indicated in Fig. 3, are both Group $C$.

Results (Table I, opposite)

The duration of the retinal detachment is indicated in weeks. Total protein is expressed in $\mathrm{g} . / \mathrm{I} 00 \mathrm{ml}$. Specific points of clinical interest are shown. Unless indicated, subretinal fluid specimens were obtained from patients undergoing an initial retinal detachment operation and retinal holes were found. One case of retinoschisis was studied.

EXAMINATION OF THE RESULTS SHOWS THE FOLLOWING:

(I) High levels of total protein concentration $(7 \mathrm{I} .5 \mathrm{~g} . / 100 \mathrm{ml}$.) are found in cases of long-standing retinal detachment (longer than 8 weeks), as shown in Table II.

Table II Protein concentration of subretinal fluid related to duration of detachment

\begin{tabular}{|c|c|c|c|c|c|c|}
\hline \multirow{3}{*}{$\begin{array}{l}\text { Duration of } \\
\text { detachment (wks) }\end{array}$} & \multicolumn{6}{|c|}{ Total protein concentration $(\mathrm{g} . / \mathrm{1} 00 \mathrm{ml})}$. \\
\hline & \multicolumn{2}{|c|}{$<\mathrm{I} \cdot \mathrm{O}$} & \multicolumn{2}{|c|}{$1-1 \cdot 50$} & \multicolumn{2}{|c|}{$>1 \cdot 50$} \\
\hline & No. & Per cent. & No. & Per cent. & No. & Per cent. \\
\hline I-4 (1 3 cases) & 7 & $53 \cdot 8$ & 6 & $46 \cdot 2$ & o & $\mathbf{o}$ \\
\hline $8+(12$ cases $)$ & 6 & 50 & 2 & $16 \cdot 7$ & 4 & $33 \cdot 3$ \\
\hline
\end{tabular}

(2) In the immunoelectrophoretic study there was a general tendency for subretinal fluid to come to resemble serum more closely, with increasing duration of detachment (i.e. towards Group A with increasing age), as shown in Table III (overleaf).

(3) There does not appear to be a constant relationship between immunoelectrophoresis grouping and total protein concentration. High total protein concentration may be associated with immunoelectrophoretic Group A (Cases 2 I, 24, and 26) or Group C 
Table I Results in 28 specimens obtained from 26 patients

\begin{tabular}{|c|c|c|c|c|}
\hline Case no. & $\begin{array}{l}\text { Duration of } \\
\text { detachment } \\
\text { (wks) }\end{array}$ & $\begin{array}{l}\text { Total protein } \\
(\mathrm{g} / \mathrm{I} \text { oo } \mathrm{ml} .)\end{array}$ & $\begin{array}{l}\text { Immuno- } \\
\text { electro- } \\
\text { phoretic group }\end{array}$ & Details of detachment \\
\hline I & $\mathbf{I}$ & $0 \cdot 94$ & C & Detachment operation 3 months previously \\
\hline 2 & $\mathbf{I}$ & $0 \cdot 99$ & $\mathrm{~A} \rightarrow \mathrm{B}$ & Aphakia \\
\hline 3 & $\mathbf{I}$ & 0.91 & A & \\
\hline 4 & $\mathbf{I}$ & $0 \cdot 69$ & $\mathbf{C}$ & \\
\hline 5 & $\mathbf{I}$ & $0 \cdot 66$ & B & \\
\hline 6 & I & I 45 & $\mathbf{C}$ & \\
\hline 7 & 2 & $\mathrm{I} \cdot 20$ & B & \\
\hline 8 & 2 & $\mathrm{I} \cdot 24$ & $\mathbf{C}$ & \\
\hline 9 & 4 & $0 \cdot 39$ & A & \\
\hline 10 & 4 & $\mathrm{I} \cdot \mathbf{2 2}$ & A & Re-operation on Case 9 \\
\hline I I & 4 & $1 \cdot 17$ & A & Aphakia \\
\hline 12 & 4 & $\mathbf{I} \cdot \mathbf{O}$ & B & \\
\hline I3 & 4 & Not done & $\mathbf{C}$ & \\
\hline 14 & 4 & 0.57 & $\mathrm{~A} \rightarrow \mathrm{B}$ & Aphakia \\
\hline I 5 & 4 & Not done & B & \\
\hline I6 & 8 & $0 \cdot 79$ & $\mathrm{~A} \rightarrow \mathrm{B}$ & Diathermy 5 yrs previously \\
\hline 17 & 8 & $0 \cdot 92$ & B & \\
\hline 18 & 8 & $0 \cdot 56$ & A & \\
\hline 19 & 8 & $0 \cdot 84$ & A & Re-operation on Case 6 \\
\hline 20 & 12 & $2 \cdot 50$ & B & \\
\hline $2 \mathrm{I}$ & 12 & $x \cdot 70$ & A & \\
\hline 22 & 12 & $\mathrm{I} \cdot 08$ & A & $\begin{array}{l}\text { Diabetic traction detachment } \\
\text { No holes }\end{array}$ \\
\hline 23 & 14 & $0 \cdot 75$ & A & $\begin{array}{l}\text { Diabetic traction detachment } \\
\text { Holes seen }\end{array}$ \\
\hline 24 & 14 & $1 \cdot 72$ & A & $\begin{array}{l}\text { No holes seen } \\
\text { Dense lens opacities }\end{array}$ \\
\hline 25 & 20 & 0.94 & B & Retinal dialysis \\
\hline 26 & 24 & $2 \cdot 44$ & A & $\begin{array}{l}\text { No holes seen } \\
\text { Congenital cataracts }\end{array}$ \\
\hline 27 & 60 & $\mathbf{1} \cdot 37$ & C & Retinoschisis \\
\hline 28 & 64 & $1 \cdot 13$ & B & \\
\hline
\end{tabular}


Table III Duration of detachment related to immunoelectrophoretic properties of subretinal fluid

\begin{tabular}{|c|c|c|c|c|c|c|c|c|}
\hline \multirow{3}{*}{$\begin{array}{l}\text { Duration of } \\
\text { detachment (wks) }\end{array}$} & \multicolumn{8}{|c|}{ Immunoelectrophoretic group } \\
\hline & \multicolumn{2}{|l|}{$\mathbf{A}$} & \multicolumn{2}{|l|}{$\mathrm{A}-\mathrm{B}$} & \multicolumn{2}{|l|}{ B } & \multicolumn{2}{|l|}{ G } \\
\hline & No. & Per cent. & No. & Per cent. & No. & Per cent. & No. & Per cent. \\
\hline $1-4$ ( 15 cases $)$ & 4 & $26 \cdot 7$ & 2 & $13 \cdot 3$ & 4 & $26 \cdot 7$ & 5 & $33 \cdot 3$ \\
\hline $8+(12$ cases $)$ & 7 & $58 \cdot 3$ & I & $8 \cdot 3$ & 4 & $33 \cdot 3$ & o & 0 \\
\hline
\end{tabular}

(Cases 6 and 8). Similarly low total protein concentration may be associated with immunoelectrophoretic Group A (e.g. Cases 3, 9, 18, 19, and 23) or Group C (Cases I and 4).

(4) Two patients in the series were studied twice. Case 9 initially showed a low total protein concentration ( $0.39 \mathrm{~g} / \mathrm{I} / 00 \mathrm{ml}$.), but this had increased $(\mathrm{I} \cdot 22 \mathrm{~g} . / 100 \mathrm{ml}$.) when a second operation was performed 3 months later (Case Io); the immunoelectrophoretic group (Group A) was unchanged. Case 6 was operated on again 3 months later (Case I9), and whereas the total protein concentration had decreased from $\mathrm{I} \cdot 45$ to $0.84 \mathrm{~g} . / 100 \mathrm{ml}$. the immunoelectrophoretic grouping had changed from $\mathbf{C}$ to $\mathbf{A}$.

(5) Case 27 showed retinoschisis. The total protein concentration was I $13 \mathrm{~g} / \mathrm{I}$. $00 \mathrm{ml}$. and few of the normal serum constituents were present on immunoelectrophoresis (Group G).

(6) Cases 22 and 23 showed diabetic detachments. Case 22 was a typical traction detachment and Case 23 had two small retinal holes in addition to the traction appearance. In both the subretinal fluid resembled normal serum (Group A).

(7) Cases I, I0, and I9 were re-operations. The total protein concentration was not notably raised. In Case I (Group G) the retina had become flat with absorption of subretinal fluid after the previous operation and had become re-detached at a later date. In Cases Io (Group A) and I9 (Group A) the subretinal fluid had not absorbed after the initial operation.

\section{Discussion}

The technique of immunoelectrophoresis used in this study shows that subretinal fluid tends to come to resemble normal serum more closely as the duration of the retinal detachment increases. IgM (M.wt 900,000) was not detected in any of the cases studied. O Table IV shows the molecular weight of proteins found in subretinal fluid and their No concentrations in normal serum as described by Dettelbach and Ritzman (1968) and Rowe (1970). The findings of the immunoelectrophoretic study suggests that the choriocapillaris and Bruch's membrane vary in their permeability. The change in the nature of subretinal fluid as the duration of the detachment increases may be explained by an increasing permeability of the chorio-capillaris, as suggested by Heath and others (1926). The absence in all cases of IgM, which has a high molecular weight, indicates that the permeability of the capillary endothelium and of Bruch's membrane is limited even in long-standing and re-operated cases, thus in no case did the subretinal fluid have protein $\mathbb{D}$ characteristics of a true exudate. A constant relationship between immunoelectrophoretic 
examination and total protein concentration was not found and it is felt that immunoelectrophoretic examination is a more reliable indicator of dysfunction of the choriocapillaris and Bruch's membrane than total protein concentration.

Table IV Molecular weight of proteins in subretinal fluid and their concentrations in serum

\begin{tabular}{|c|c|c|}
\hline Proteins & $\begin{array}{l}\text { Molecular } \\
\text { weight }\end{array}$ & $\begin{array}{l}\text { Concentration in } \\
\text { serum }(\mathrm{mg} . / 100 \mathrm{ml} .)\end{array}$ \\
\hline Albumin & 69,000 & $3,500-4,500$ \\
\hline$a_{1}$ Antitrypsin & 45,000 & $210-500$ \\
\hline Gc-globulin & 50,800 & $40-\quad 75$ \\
\hline Haptoglobin & 100,000 & $30-190$ \\
\hline Haemopexin & 80,000 & $80-100$ \\
\hline Transferrin & 90,000 & $230-320$ \\
\hline $\operatorname{Ig} \mathrm{A}$ & 186,000 & $156-294$ \\
\hline IgG & 150,000 & $853^{-1,463}$ \\
\hline
\end{tabular}

\section{Summary}

In 28 specimens of subretinal fluid obtained from 26 patients the following observations were made:

(x) High total protein concentration levels are found in long-standing retinal detachments. This confirms the work of others.

(2) The technique of immunoelectrophoresis used in this study enabled a more detailed examination of subretinal fluid to be made than has previously been reported. Subretinal fluid comes to resemble normal serum more closely with increasing duration of the detachment. IgG and IgA were detected but IgM was absent. The findings support the theory of a limited semipermeability of the endothelium of the chorio-capillaris and of Bruch's membrane in patients with retinal detachments.

(3) There is no apparent relationship between immunoelectrophoretic findings and total protein concentration estimations. It is suggested that immunoelectrophoretic examinations offer a more reliable indicator of chorio-capillaris dysfunction than do total protein concentration estimations.

Our thanks are due to Prof. Norman Ashton for advice and laboratory facilities, and to Miss G. Munn, Miss E. Willmott, and Mr. J. Bentil for technical assistance. Mr. L. G. Fison and other members of the Retinal Unit, Moorfields Eye Hospital, City Road Branch, kindly allowed their cases to be studied. Mrs. E. Burr and the Audio-visual Department of the Institute helped in the preparation of the manuscript. This work was in part supported by the Leverhulme Trust and the Clothmakers' Company.

\section{References}

Carruthers, M. E. (1970) J. clin. Path., 23, $45^{\circ}$

COOPER, W. C., HALBERT, s. P., and MANSKI, W. J. (1963) Invest. Ophthal., 2, 369 
DetTelbach, H. R., and Ritzman, S. E. (1968) “Laboratory Notes for Medical Diagnostics" (August).

Hoechst Pharmaceutical, London

GRABAR, P., and williams, C. A. (1953) Biochim. biophys. Acta, ro, 193

HEATH, H., BECK, T. C., and Foulds, w. c. (1962) Brit. J. Ophthal., 46, 385

MANUel, Y., ROYer, J., Richard, G., and CReysSel, R. (1960) Ann. Oculist. (Pairis), 193, 739

ROWE, D. S. (1970) Nature (Lond.), 228, 509

SCHEIDEgGer, J. J. (1955) Int. Arch. Allerg., 7, I03

SMIth, J. L., and Douty, E. (1960) A.M.A. Arch. Ophthal., 64, I I 4

SPEISER, P. (1964) Ophthalmologica (Basel), 147, 29 I

WeBer, J. c., and wilson, F. м. (1963) Arch. Ophthal. (Chicago), 69, 363

- (1966) Invest. Ophthal., 5, 323 